\title{
STIMULASI PERKEMBANGAN NILAI-NILAI AGAMA DAN MORAL PADA ANAK USIA DINI MELALUI ESTETIKA GERAK PERMAINAN TRADISIONAL MASYARAKAT YOGYAKARTA
}

\author{
Joko Pamungkas \\ Universitas Negeri Yogyakarta \\ Email: joko_anoman@yahoo.com
}

\begin{abstract}
Abstrak
Penelitian ini bertujuan untuk mendeskripsikan stimulasi perkembangan nilai-nilai agama dan moral pada Anak Usia Dini melalui estetika gerak permainan tradisional masyarakat Yogyakarta. Jenis penelitian adalah penelitian tindakan dengan menggunakan pendekatan siklus. Langkah penelitian siklus dimulai dari memilih arah penelitian, mengumpulkan data, menganalisa dan menafsirkan data, mengambil tindakan, merefleksikan hasil tindakan, memperbaharui tindakan dan melanjutkan kembali penelitian ke langkah awal, yaitu memilih arah penelitian lebih khusus dan seterusnya. Teknik pengumpulan data menggunakan observasi dan wawancara dengan teknik analisis data interaktif dari Miles \& Hubberman. Hasil penelitian menunjukkan siklus I terdapat prosentase $64 \%$, siklus II $78 \%$, dan siklus III sebesar $83 \%$ yang berarti bahwa permainan tradisional berpengaruh positif terhadap perkembangan moral anak. Permainan yang digunakan adalah ular naga, cublak-cublak suweng pada siklus I. Siklus II menggunakan suksuk pari ambruk dan jamuran. Siklus III menggunakan permainan sim-sim terimakasim.
\end{abstract}

Kata kunci: stimulasi perkembangan, nilai agama, moral, estetika, permainan tradisional Yogyakarta

\section{STIMULATING THE DEVELOPMENT OF MORALITY AND RELIGIOUS VALUES THROUGH AESTHETICS MOTIONS OF YOGYAKARTAN TRADITIONAL GAMES FOR EARLY CHILDHOOD}

\begin{abstract}
This study aimed to describe the stimulation of the development of religious values and morals on Early Childhood through motion aesthetics of traditional games people of Yogyakarta. This type of research is to use action research cycle approach. Step research cycle starts from choosing the direction of research, collect data, analyze and interpret the data, take action, reflecting the results of the action, renewing action and resume the investigation into the initial step, choosing the direction of more specialized research and data collection. To observation and interviews with interactive data analysis technique using Miles \& Hubberman. The results show there is a percentage of the first cycle $64 \%, 78 \%$ the second cycle, and the third cycle of $83 \%$, which means that the traditional game a positive effect on the moral development of children. The game used is the serpent, cublak-cublak suweng in cycle I. Cycle II using a suk-suk pari ambruk and jamuran. Cycle III using sim-sim terimakasim game.
\end{abstract}

Keywords: stimulation of development, religious values, moral, aesthetic, game traditional Yogyakarta

\section{PENDAHULUAN}

Nilai kesabaran telah hilang ditelan teknologi. Anak belum berkembang motorik halusnya sudah dilatih bermain game di handphone orang tuanya yang canggih. Anak belum dapat berhitung dengan jari tetapi sudah terbiasa menggunakan mesin kalkulator. Anak belum dapat mengancing- 
kan baju sendiri tetapi pakaian kotornya cukup dititipkan ke jasa laundry. Anak tidak tahu dari mana asalnya nasi tetapi anak lahap mengonsumsi makanan cepat saji. Dampaknya adalah lahir generasi anak yang serba tergantung pada teknologi dan lemah daya juangnya dalam merawat kehidupannya sendiri.

Grand tour penelitian ini dimulai dari stimulasi apa saja yang dilakukan pada anak usia dini. Hal ini peneliti dasarkan pada bermacam lingkup perkembangan anak yang meliputi aspek: agama, sosial emosional, fisik motorik, bahasa, dan kognitif. Stimulasi aspek perkembangan tersebut tentu saja salah satunya bersandar pada tingkat pencapaian perkembangan pada PP 58 tahun 2009. Permainan sebagai "obat" dalam penelitian tindakan ini didasari dari permen 58 tahun 2009 yang menyatakan bahwa guru pada PAUD harus memiliki kemampuan untuk melaksanakan proses pendidikan, pengasuhan, dan perlindungan pada anak yang mempunyai indikator yaitu menggunakan metode pembelajaran melalui bermain sesuai dengan karakteristik anak. Berdasarkan uraian ini maka permainan memang cukup mempunyai andil positif dalam pembelajaran.

Kenyataan di lapangan menunjukkan bahwa pelaksanaan pendidikan di Taman Penitipan Anak \& Kelompok Bermain Yoga Dharma Santi masih sebatas penitipan anak dan belum ada layanan pembelajaran. Oleh karena itu, secara langsung dapat dikatakan bahwa tidak ada catatan aspek perkembangan yang semestinya dan dalam pembelajaran anak. Oleh karena itu Terkait hal tersebut maka nilai-nilai agama,moral, dan estetika merupakan hal baru yang perlu dicari deskripsi stimulasinya.

\section{METODE}

Jenis Penelitian

Jenis penelitian yang digunakan dalam penelitian ini adalah penelitian tindakan
(Gall, Gall, \& Borg, 2007:597-628) dengan menggunakan pendekatan siklus.

\section{Subjek dan Objek Penelitian}

Subjek Penelitian ini adalah anak-anak usia 0 sampai dengan 4 tahun di TPA \& KB Yoga Dharma Santi, Sleman, Yogyakarta. Objek penelitian ini adalah nilai agama moral dan nilai estetika gerak.

\section{Lokasi Penelitian}

Penelitian ini dilaksanakan pada bulan April sampai dengan Agustus 2014 di Taman Penitipan Anak \& Kelompok Bermain Yoga Dharma Santi, Sleman, Yogyakarta. Teknik Pengumpulan Data adalah observasi dan wawancara. Instrumen pengumpul data penelitian ini menggunakan instrumen berupa lembar observasi dan pedoman wawancara.

\section{Rancangan Penelitian}

Langkah penelitian siklus dimulai dari memilih arah penelitian, mengumpulkan data, menganalisa dan menafsirkan data, mengambil tindakan, merefleksikan hasil tindakan, memperbaharui tindakan dan melanjutkan kembali penelitian ke langkah awal, yaitu memilih arah penelitian lebih khusus dan seterusnya.

\section{Metode Pengumpulan Data}

Perencanaan tindakan pada siklus pertama diawali dengan mengobservasi pelaksanaan pendidikan di Taman Penitipan Anak \& Kelompok Bermain Yoga Dharma Santi untuk menentukan arah penelitian. Hasil observasi menunjukan bahwa pelaksanaan pendidikan di Taman Penitipan Anak \& Kelompok Bermain Yoga Dharma Santi masih sebatas penitipan anak dan belum ada layanan pembelajaran. Oleh karena itu, direncanakanlah pembelajaran untuk anak melalui permainan tradisional ular naga, cublak-cublak suweng, suk-suk pari ambruk, jamuran, dan sim-sim terimakasim untuk menstimulasi gerak estetik dan moral anak usia dini. 
Tabel 1. Kisi-kisi Observasi Nilai Moral \& Estetika

\begin{tabular}{|c|c|}
\hline $\begin{array}{c}\text { Variabel } \\
\text { Penelitian }\end{array}$ & Indikator \\
\hline \multirow{2}{*}{$\begin{array}{l}\text { Nilai Agama- } \\
\text { Moral }\end{array}$} & Tanggung jawab \\
\hline & Kepedulian \\
\hline \multirow[t]{2}{*}{ Nilai Estetika } & Kerjasama \\
\hline & Kedisiplinan \\
\hline
\end{tabular}

\section{Analisis Data}

Analisis data dalam penelitian ini menggunakan analisis interaktif antara data empirik stimulasi nilai-nilai agama, moral, dan estetika anak usia dini dengan teori tentang perkembangan nilai-nilai agama, moral, dan estetika anak usia dini.

\section{HASIL DAN PEMBAHASAN Pratindakan}

Perencanaan tindakan pada siklus pertama diawali dengan mengobservasi pelaksanaan pendidikan di Taman Penitipan Anak \& Kelompok Bermain Yoga Dharma Santi untuk menentukan arah penelitian. Hasil observasi menunjukan bahwa pelaksanaan pendidikan di Taman Penitipan Anak \& Kelompok Bermain Yoga Dharma Santi masih sebatas penitipan anak dan belum ada layanan pembelajaran sehingga penelitian ini terbatas pada tindakan melalui permainan tradisional untuk mengamati kemampuan nilai moral dan gerak estetis.

\section{Siklus Pertama}

Siklus Pertama menggunakan dua jenis permainan tradisional untuk stimulasi gerak estetik dan moral anak usia dini, yaitu ular naga dan cublak-cublak suweng. Hasil observasi pelaksanaan permainan ular naga dan cublak-cublak suweng terekam dalam bentuk skor gerak estetis anak dan skor perkembangan moral anak. Hipotesis tindakan siklus pertama adalah bagaimana gerak estetik permainan tradisional ular naga dan cublak-cublak suweng dapat mengembangkan nilai-nilai moral dan agama pada anak usia dini di Taman Penitipan Anak \& Kelompok Bermain Yoga Dharma Santi. Pengumpulan data menggunakan lembar observasi terhadap gerak estetik dan perkembangn moral anak pada saat melakukan permainan tradisional ular naga dan cublak-cublak suweng. Penilaian terhadap hasil pengamatan menggunakan skala 3, yaitu skor 1 berarti gerak bersifat kaku, skor 2 berarti gerak bersifat agak lentur, dan skor 3 berarti gerak sangat lentur untuk variabel estetika gerak, sedangkan untuk variabel perkembangan moral, skor 1 berarti jarang melakukan nilai moral yang diamati, skor 2 berarti kadang-kadang melakukan nilai moral yang diamati, dan skor 3 berarti sering melakukan nilai moral yang diamati. Hasil olah data penelitian pada siklus pertama terangkum dalam tabel tabulasi data berikut.

Tabel 2. Tabulasi Data Stimulasi Gerak Estetik dan Perkembangan Moral Anak pada Siklus Pertama

\begin{tabular}{ccc}
\hline INISIAL & GERAK & MORAL \\
\hline AS & 6 & 7 \\
WN & 5 & 6 \\
EK & 6 & 7 \\
FZ & 7 & 8 \\
YS & 6 & 8 \\
TS & 5 & 7 \\
TT & 7 & 7 \\
RW & 5 & 6 \\
JP & 6 & 8 \\
\hline
\end{tabular}

Berdasarkan tabulasi data tersebut disusunlah model SEM-PLS (Hair et al, 2013:3) yang diajukan beserta indikatornya, yaitu variabel estetika gerak diukur dengan satu indikator yang diberi nama "gerak", dan variabel perkembangan moral anak diukur dengan satu indikator juga yang diberi nama "moral". Adapun gambar model yang diajukan untuk siklus pertama adalah sebagai berikut. 


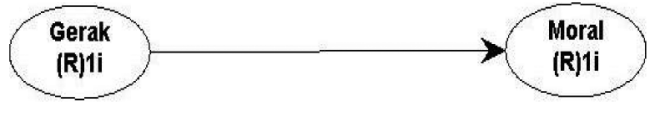

Gambar 1. Model Stimulasi Gerak Estetis Mengembangkan Moral Anak

Selanjutnya model tersebut dianalisis dengan program SEM-PLS WarpPLS 3.0 (Mahfud Sholihin dan Dwi Ratmoko, 2013:48) untuk mengestimasi apakah model tersebut menjawab hipotesis tindakan atau tidak. Out put dari analisis tersebut menunjukan bahwa stimulasi gerak estetis dapat mengembangkan moral anak sebesar $64 \%$ seperti tercantum dalam skor koefisien sama dengan 0.64 dan nilai $\mathrm{p}<0,01$.

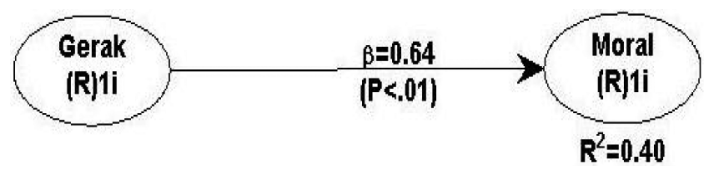

Gambar 2. Hasil Estimasi Model Stimulasi Gerak Estetis Mengembangkan Moral Anak

Plot hubungan stimulasi gerak estetis dengan pengembangan moral anak dapat dilihat pada gambar di bawah ini.

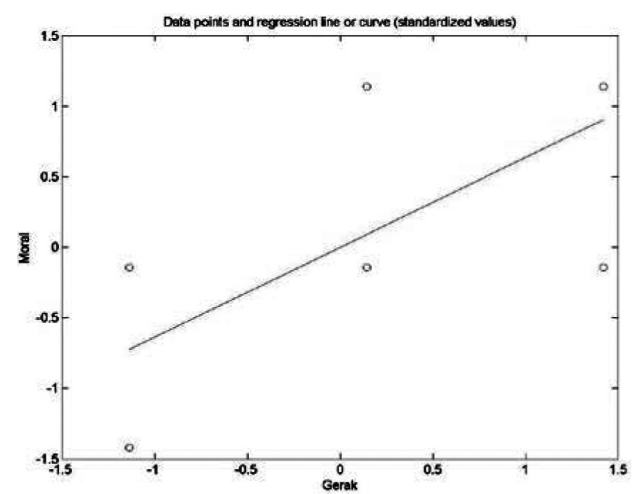

Gambar 3. Plot Hubungan Gerak dan Moral

Refleksi permainan tradisional ular naga dan cublak-cublak suweng adalah sebagai berikut. Pada permainan ular naga, anak-anak yang tertangkap mengekspresi- kan ketidaknyamanan secara emosional meskipun mereka tersenyum. Anak-anak lebih suka menjadi gerbong daripada menjadi terowongan. Demikian pula pada permainan cublak-cublak suweng, anakanak belum mengerti apabila pendidik menyuruh untuk menyembunyikan benda tersebut, anak-anak yang mendapatkan benda cenderung mengatakan "aku" sambil memperlihatkan bendanya ke temanteman. Kendala yang lain, anak tidak mau bergantian menjadi meja di tengah permainan. Untuk memperbaiki keadaan ini, maka pada siklus kedua akan diujicobakan permainan tradisional suk-suk pariambruk dan jamuran.

\section{Siklus Kedua}

Siklus kedua direncanakan menggunakan dua jenis permainan tradisional untuk stimulasi gerak estetik dan moral anak usia dini, yaitu suk-suk pariambruk dan jamuran. Hasil observasi pelaksanaan permainan tradisional suk-suk pariambruk dan jamuran terekam dalam bentuk skor gerak estetis anak dan skor perkembangan moral anak. Hipotesis tindakan siklus kedua adalah bagaimana gerak estetik permainan tradisional suk-suk pariambruk dan jamuran dapat mengembangkan nilainilai moral dan agama pada anak usia dini di Taman Penitipan Anak \& Kelompok Bermain Yoga Dharma Santi. Pengumpulan data menggunakan lembar observasi terhadap gerak estetik dan perkembangan moral anak pada saat melakukan permainan tradisional suk-suk pariambruk dan jamuran. Penilaian terhadap hasil pengamatan menggunakan skala 3, yaitu skor 1 berarti gerak bersifat kaku, skor 2 berarti gerak bersifat agak lentur, dan skor 3 berarti gerak sangat lentur untuk variabel estetika gerak, sedangkan untuk variabel perkembangan moral, skor 1 berarti jarang melakukan nilai moral yang diamati, skor 2 berarti kadang-kadang melakukan nilai moral yang diamati, dan skor 3 berarti sering melakukan nilai moral 
yang diamati. Hasil olah data penelitian pada siklus kedua terangkum dalam tabel tabulasi data berikut.

Tabel 3. Tabulasi Data Stimulasi Gerak Estetik dan Perkembangan Moral Anak pada Siklus Pertama

\begin{tabular}{ccc}
\hline INISIAL & GERAK & MORAL \\
\hline AS & 8 & 7 \\
WN & 6 & 8 \\
EK & 3 & 5 \\
FZ & 4 & 6 \\
YS & 5 & 7 \\
TS & 4 & 5 \\
TT & 6 & 7 \\
RW & 7 & 7 \\
JP & 7 & 8 \\
\hline
\end{tabular}

Berdasarkan tabulasi data tersebut disusunlah model SEM-PLS yang diajukan beserta indikatornya, yaitu variabel estetika gerak diukur dengan satu indikator yang diberi nama "gerak", dan variabel perkembangan moral anak diukur dengan satu indikator juga yang diberi nama "moral". Adapun gambar model yang diajukan untuk siklus kedua adalah sebagai berikut.

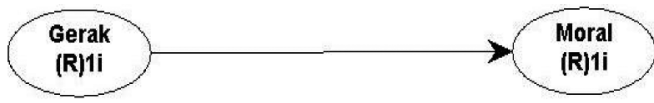

Gambar 4. Model Stimulasi Gerak Estetis Mengembangkan Moral Anak

Selanjutnya model tersebut dianalisis dengan program SEM-PLS WarpPLS 3.0 untuk mengestimasi apakah model tersebut menjawab hipotesis tindakan atau tidak. Out put dari analisis tersebut menunjukan bahwa stimulasi gerak estetis dapat mengembangkan moral anak sebesar $78 \%$ seperti tercantum dalam skor koefisien sama dengan 0.78 dan nilai $\mathrm{p}<0,01$.

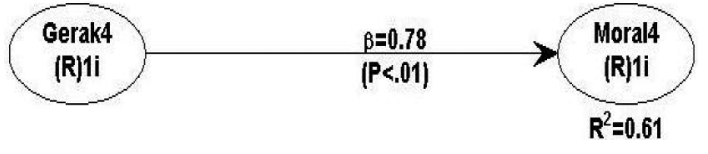

Gambar 5. Hasil Estimasi Model Stimulasi Gerak Estetis Mengembangkan Moral Anak

Plot hubungan stimulasi gerak estetis dengan pengembangan moral anak dapat dilihat pada gambar di bawah ini.

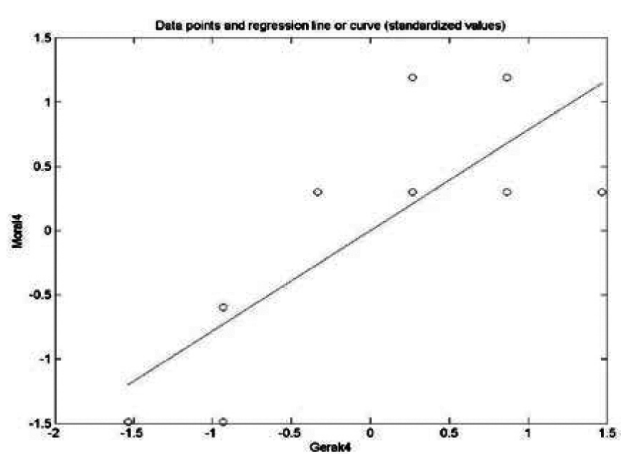

Gambar 6. Plot Hubungan Gerak dan Moral

Refleksi permainan tradisional suk-suk pariambruk dan jamuran adalah sebagai berikut. Proses pelaksanaan permainan tradisional suk-suk pariambruk, anak-anak cenderung diam dan malas untuk bergerak, bahkan menyanyi pun tak mau, hanya beberapa anak yang mengikuti permainan ini namun tidak secara utuh ikut menggerakan badannya ke kanan dan ke kiri. Demikian pula pada proses pelaksanaan permainan tradisional jamuran, anak-anak masih bingung bagaimana cara menirukan gerak hewan, mereka hanya diam dan menatap pendidik yang memberikan contoh.

\section{Siklus Ketiga}

Siklus ketiga direncanakan menggunakan satu jenis permainan tradisional untuk stimulasi gerak estetik dan moral anak usia dini, yaitu sim-sim terimakasim. Hasil observasi pelaksanaan permainan tradisional sim-sim terimakasim terekam 
dalam bentuk skor gerak estetis anak dan skor perkembangan moral anak. Hipotesis tindakan siklus ketiga adalah bagaimana gerak estetik permainan tradisional simsim terimakasim dapat mengembangkan nilai-nilai moral dan agama pada anak usia dini di Taman Penitipan Anak \& Kelompok Bermain Yoga Dharma Santi. Pengumpulan data menggunakan lembar observasi terhadap gerak estetik dan perkembangan moral anak pada saat melakukan permainan tradisional simsim terimakasim. Penilaian terhadap hasil pengamatan menggunakan skala 3, yaitu skor 1 berarti gerak bersifat kaku, skor 2 berarti gerak bersifat agak lentur, dan skor 3 berarti gerak sangat lentur untuk variabel estetika gerak, sedangkan untuk variabel perkembangan moral, skor 1 berarti jarang melakukan nilai moral yang diamati, skor 2 berarti kadang-kadang melakukan nilai moral yang diamati, dan skor 3 berarti sering melakukan nilai moral yang diamati. Hasil olah data penelitian pada siklus ketiga terangkum dalam tabel tabulasi data berikut.

Tabel 4. Tabulasi Data Stimulasi Gerak Estetik dan Perkembangan Moral Anak pada Siklus Ketiga

\begin{tabular}{ccc}
\hline INISIAL & GERAK & MORAL \\
\hline AS & 6 & 7 \\
WN & 5 & 7 \\
EK & 6 & 6 \\
FZ & 4 & 5 \\
YS & 5 & 6 \\
TS & 4 & 6 \\
TT & 4 & 5 \\
RW & 7 & 8 \\
JP & 5 & 6 \\
\hline
\end{tabular}

Berdasarkan tabulasi data tersebut disusunlah model SEM-PLS yang diajukan beserta indikatornya, yaitu variabel estetika gerak diukur dengan satu indikator yang diberi nama "gerak", dan variabel perkembangan moral anak diukur dengan satu indikator juga yang diberi nama "moral". Adapun gambar model yang diajukan untuk siklus ketiga adalah sebagai berikut.

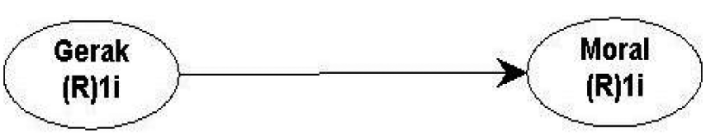

Gambar 7. Model Stimulasi Gerak Estetis Mengembangkan Moral Anak

Selanjutnya model tersebut dianalisis dengan program SEM-PLS WarpPLS 3.0 untuk mengestimasi apakah model tersebut menjawab hipotesis tindakan atau tidak. Out put dari analisis tersebut menunjukan bahwa stimulasi gerak estetis dapat mengembangkan moral anak sebesar $83 \%$ seperti tercantum dalam skor koefisien sama dengan 0.83 dan nilai $\mathrm{p}<0,01$.

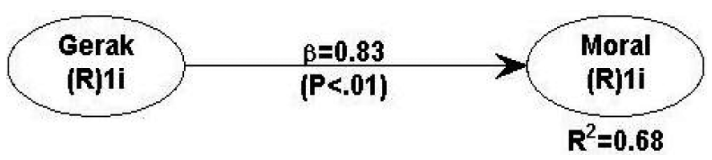

Gambar 8. Hasil Estimasi Model Stimulasi Gerak Estetis Mengembangkan Moral Anak

Plot hubungan stimulasi gerak estetis dengan pengembangan moral anak dapat dilihat pada gambar di bawah ini.

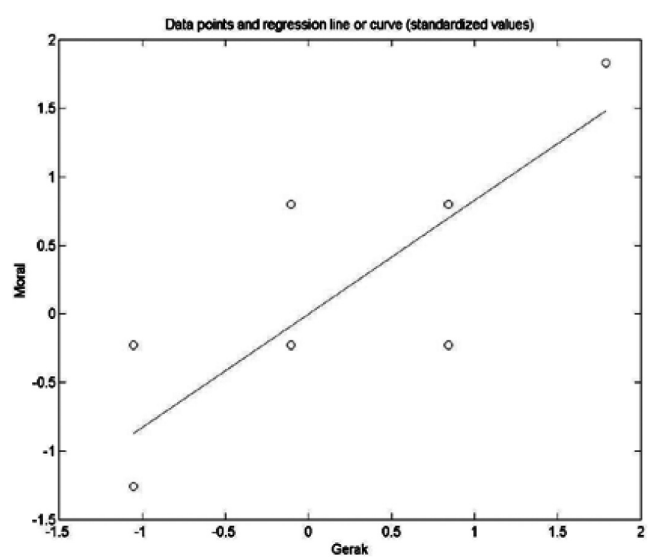

Gambar 9. Plot Hubungan Gerak dan Moral 
Refleksi permainan tradisional simsim terimakasim adalah sebagai berikut. Pada sepuluh menit pertama, anak-anak antusias bermain sim-sim terimakasim. Namun beberapa saat kemudian anak mulai meninggalkan area bermain. Mereka sama sekali tidak dapat memusatkan perhatian mereka pada satu hal dalam waktu cukup lama. Dengan kata lain, anak-anak mudah berubah pikiran untuk melakukan kegiatan lainnya yang lebih menarik.

\section{Pembahasan}

Berdasarkan paparan data di atas, maka akan didiskusikan tentang proses stimulasi perkembangan moral anak melalui estetika gerak permainan tradisional. Pada siklus pertama, proses permainan tradisional ular naga dan cublak-cublak suweng menstimulasi perkembangan moral anak seperti tanggung jawab, kepedulian, kerjasama, dan kedisiplinan. Anak-anak diajak membentuk lingkaran besar dan lingkaran kecil sebagai kegiatan apersepsi sebelum masuk ke permainan ular naga merupakan stimulasi nilai moral kerjasama. Pendidik memberi contoh membuat terowongan kereta dengan mempertemukan dua tangan pendidik, contoh membuat rangkaian kereta yang terdiri dari beberapa anak sebagai gerbongnya, dan contoh menangkap anak ketika lagu habis merupakan stimulasi nilai tanggung jawab, kepedulian, dan kedisiplinan. Anak-anak diminta ada yang menjadi terowongan dua orang, dan sisanya membentuk rangkaian gerbong kereta api. Putaran pertama lagu belum habis sehingga belum ada anak yang tertangkap dan tengah-tengah putaran kedua lagu habis sehingga tertangkap satu anak untuk menggantikan anak lain menjadi terowongan merupakan stimulasi nilai moral tanggung jawab, kerjasama, kepedulian kepada anak yang tidak beruntung, dan kedisiplinan sesuai dan terhadap masing-masing peran dalam bermain ular naga. Ada satu anak yang berperan sebagai meja. Anak-anak lain menjulurkan tangan masing-masing secara terbuka di atas meja dari punggung salah satu anak. Kemudian sebuah permen diletakkan di salah satu tangan terbuka untuk dipindahkan ke tangan di sampingnya sambil diiringi nyanyian. Apabila nyanyian habis, dan anak yang memegang permen maupun anak lain harus mengepalkan tangan, dan anak yang bermain peran sebagai meja harus menebak di tangan siapa permen itu berada. Apabila berhasil ditebak, maka anak yang pegang permen akan berganti peran menjadi meja dari semula peserta. Kegiatan bermain ini merupakan stimulasi nilai tanggung jawab, disiplin, peduli, dan bekerjasama dengan anak lain.

Secara kuantitatif deskriptif pada siklus pertama, rerata skor gerak estetika sebesar 5,88 dengan simpangan baku 0,78 dan rerata skor perkembangan moral sebesar 7,11 dengan simpangan baku 0,78. Kesimpulannya gerak estetika permainan tradisional ular naga dan cublak-cublak suweng berpengaruh positif terhadap perkembangan moral anak sebesar $64 \%$ pada siklus pertama.

Pada siklus kedua, proses permainan tradisional suk-sukpariambruk dan jamuran menstimulasi perkembangan moral anak seperti tanggung jawab, kepedulian, kerjasama, dan kedisiplinan. Contoh kegiatan bermain berikut ini merupakan proses stimulasi perkembangan moral tanggung jawab, peduli, kerjasama, dan disiplin. Pendidik dan anak-anak saling berpegangan tangan membentuk lingkaran besar, kemudian lingkaran kecil, lingkaran besar lagi, lingkaran kecil lagi, lingkaran besar lagi, dan terakhir membentuk lingkaran kecil sambil bernyanyi. Kemudian tiga orang pendidik memberi contoh permainan suk-suk pariambruk dengan cara berbaris lurus mengikuti urutan pola lantai keramik secara horizontal. Masing-masing pendidik menirukan pohon padi yang tertiup angin ambruk ke kanan kemudian ambruk lagi ke kiri sambil menyanyikan 
lagu. Berikutnya adalah giliran anak-anak barmain suk-suk pariambruk. Anak-anak meliukan badan ke kiri dan ke kanan sambil bernyanyi sampai mereka lelah bermain merupakan stimulasi nilai perkembangan moral kerjasama dan kepedulian.

Pendidik dan anak-anak saling berpegangan tangan membentuk lingkaran besar, kemudian lingkaran kecil, lingkaran besar lagi, lingkaran kecil lagi, lingkaran besar lagi, dan terakhir membentuk lingkaran kecil sambil bernyanyi. Pendidik memberi contoh bermain jamuran, yaitu ada satu pendidik yang berdiri di tengah lingkaran kemudian lingkaran anak-anak dan pendidik lain bergerak mengitari pendidik yang ada di tengah sambil menyanyikan lagu. Jika lagu selesai dinyanyikan, anak-anak dan pendidik berjongkok dan menanyakan jamur apa kepada pendidik yang ada di tengah. Jika pendidik yang di tengah jawab jamur ayam, maka anak-anak dan pendidik lain menirukan gerakan ayam berjalan dan menirukan suara ayam berkokok. Jika pendidik yang di tengah jawab jamur kambing, maka anak-anak dan pendidik lain menirukan gerak kambing berjalan dan menirukan suara kambing mengembik. Semua kegiatan bermain di atas merupakan stimulasi perkembangan moral kerjasama, kepedulian, tanggung jawab dan kedisiplinan.

Secara kuantitatif deskriptif pada siklus kedua, rerata skor gerak estetika sebesar 5,55 dengan simpangan baku 1,66 dan rerata skor perkembangan moral sebesar 6,66 dengan simpangan baku 1,11. Kesimpulannya gerak estetika permainan tradisional suk-suk pariambruk dan jamuran berpengaruh positif terhadap perkembangan moral anak sebesar $78 \%$ pada siklus kedua.

Pada siklus ketiga, proses permainan tradisional sim-sim terimakasim menstimulasi perkembangan moral anak seperti tanggung jawab, kepedulian, kerjasama, dan kedisiplinan. Contoh kegiatan bermain berikut ini merupakan proses stimu- lasi perkembangan moral tanggung jawab, peduli, kerjasama, dan disiplin. Pendidik dan anak-anak saling berpegangan tangan membentuk lingkaran besar, kemudian lingkaran kecil, lingkaran besar lagi, lingkaran kecil lagi, lingkaran besar lagi, dan terakhir membentuk lingkaran kecil sambil bernyanyi. Kemudian dilanjutkan dengan bermain sim-sim terimakasim. Masing-masing anak dipasangkan per dua orang. Pendidik memberi contoh dengan berpasangan bersama pendidik lain untuk beradu tepuk, tangan kiri bertemu tangan kiri dan tangan kanan bertemu tangan kanan. Sambil diringi lagu, anak bermain saling tepuk dengan penuh suka cita sampai iringan lagu selesai, kemudian bernyanyi lagi sampai semua anak mengalami bermain sim-sim terimakasim.

Secara kuantitatif deskriptif pada siklus ketiga, rerata skor gerak estetika sebesar 5,11 dengan simpangan baku 1,05 dan rerata skor perkembangan moral sebesar 6,22 dengan simpangan baku 0,97. Kesimpulannya gerak estetika permainan tradisional sim-sim terimakasim berpengaruh positif terhadap perkembangan moral anak sebesar $83 \%$ pada siklus ketiga.

\section{PENUTUP}

\section{Simpulan}

Bermain estetika gerak melalui permainan tradisional masyarakat Yogyakarta seperti ular naga, cublak-cublak suweng, suk-suk pariambruk, jamuran, dan sim-sim terimakasim dapat berpengaruh positif pada perkembangan moral anak usia dini di TPA KB Yoga Dharma Santi. Hal ini didukung oleh data empirik pada siklus pertama yang menunjukkan bahwa kegiatan permainan tradisional ular naga dan cublak-cublak suweng berpengaruh positif sebesar $64 \%$ terhadap perkembangan moral anak. Pada siklus kedua menunjukan bahwa kegiatan permainan tradisional suk-sukpariambruk dan jamuran berpengaruh positif sebesar $78 \%$ terhadap perkembangan moral anak. Pada siklus 
ketiga menunjukan bahwa kegiatan permainan tradisional sim-sim terimakasim berpengaruh positif sebesar $83 \%$ terhadap perkembangan moral anak.

\section{Saran}

Bagi anak-anak, permainan tradisional ular naga, cublak-cublak suweng, suk-suk pari ambruk, jamuran, dan sim-sim terimakasim dapat menstimulasi gerak estetik dan moral.

\section{DAFTAR PUSTAKA}

Gall, M.D., Gall, J.P., dan Borg, W.R. (2007). Educational Research: An Introduction. Boston: Pearson Education Inc.
Hair, J.F., et al. (2013). A Primer on Partial Least-Squares Structural Equation Modeling (SEM-PLS). Los Angeles: Sage, electronic vertion.

Mahfud Sholihin dan Dwi Ratmono. (2013). Analisis Sem-Pls dengan Warppls 3.0 untuk Hubungan Nonlinier dalam Penelitian Sosial dan Bisnis. Yogyakarta: Andi Offset.

Peraturan Menteri Pendidikan Nasional RI Nomor 58 tahun 2009 tentang Standar Pendidikan Anak Usia Dini. Tanpa nama kota: tanpa nama penerbit. 